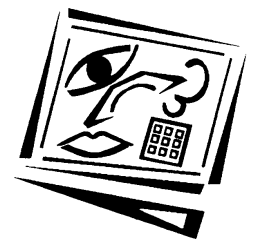

\title{
Collaborative e-learning course design: Impacts on instructors in the Open University of Tanzania
}

Kassimu A. Nihuka

Open University of Tanzania

Joke Voogt

University of Twente

\begin{abstract}
Efforts by universities in sub-Sahara Africa to promote professional development of instructors in course design and delivery by e-learning technologies have often lacked meaningful impacts. This study investigated the impact of collaborative course design on instructors' professional learning about design and delivery of e-learning courses at the Open University of Tanzania (OUT). Six Teacher Design Teams (TDTs), each with 2 instructors, participated in the study, redesigning their print-based courses using an offline Moodle LMS supported by emails and mobile phones. A total of 36 interviews were conducted with 12 instructors, after each of the two workshops and after the course redesign process. Results showed that despite challenges, instructors were satisfied with collaborative course design and they reported that the strategy contributed to their professional learning. Instructors' backgrounds determined the kinds of support needed during course design and delivery.
\end{abstract}

\section{Introduction}

Distance education in sub-Saharan Africa is still characterised by the distribution of printed materials. However, the approach is associated with challenges which hamper student learning (Dzakiria, 2004), including (i) delays in the delivery of course outlines and study materials, and untimely access to learning resources, (ii) lack of regular and effective communication between instructors and students, (iii) lack of immediate feedback from instructors to students about their learning, and (iv) outdated learning resources and (v) feelings of isolation. A similar situation exists at the Open University of Tanzania (OUT) (Mnyanyi \& Mbwette, 2009; Nihuka \& Voogt, 2011a).

E-learning technologies are considered to offer solutions for these problems. However, the application of e-learning technologies in developing countries is limited (e.g. Dzakiria, 2004; Mnyanyi \& Mbwette, 2009), due to challenges instructors and students in most developing countries face. According to Resta and Laferriere (2008), only 4\% of the African population has access to computers and the Internet. Narrow bandwidth is another challenge. Gakio (2006, p. 41) summarises the state of Internet connectivity in tertiary institutions in Africa as "too little, too expensive and poorly managed; as a result Internet technology becomes even less useful for research and education purposes". Other challenges are the lack of ready access to e-learning technologies by both instructors and students in most developing countries (e.g. Aguti \& Fraser, 2006) and limited competencies in e-learning technologies amongst both instructors and students (e.g. Hoven, 2000). 
In an attempt to address challenges related to the limited competencies of instructors with regard to e-learning, OUT has organised professional development programs (mostly workshops and seminars) to prepare instructors for e-learning integration. However, these efforts generally did not lead to changes in instructors' practices. Instructors have continued delivering courses in the traditional way, using print despite having access to newer technologies based on computers and the Internet (Nihuka \& Voogt, 2011b).

As the literature shows that collaborative course design has the potential to prepare instructors for the implementation of curriculum innovations (Penuel, Fishman, Yamaguchi \& Gallagher, 2007; Mishra, Koehler \& Zhao, 2007; Voogt, 2010), this strategy was piloted at OUT to determine its potential for preparing instructors to undertake e-learning course redesign and delivery. This formed the focus of the current study.

\section{Collaborative course design in Teacher Design Teams}

\section{Collaborative design and professional development}

Collaboration between instructors, in particular in the form of collaborative course design, has gained popularity as a strategy for professional development in the developed world (e.g. Handelzalts, 2009; Mishra et al. 2007; Penuel et al., 2007; Waddoups, Nancy \& Earle, 2004). The reason is that participation in well-scaffolded, collaborative curriculum design processes has the potential to contribute to the professional development of the instructors involved (e.g. Borko, 2004; Parke \& Coble, 1997) and to the production of curriculum materials which are valid and feasible in practice (Loucks-Horsley, Hewson, Love \& Stiles, 1998; Penuel et al. 2007).

Collaboration and collaborative course design in Teacher Design Teams (TDTs) contributes to improved professional development of instructors (Desimone, Porter, Garet, Yoon \& Birman, 2002; Mishra et al., 2007; Voogt, Almekinders, Van den Akker \& Moonen, 2005). This is because collaborative course design in TDTs engages instructors in the investigation of problems in their educational practice, enactment of the design process when (re-) designing courses, and delivery and evaluation of the (re-designed) courses (Handelzalts, 2009). Also, collaborative design contributes to improvement of instructors' knowledge and skillss in course design (e.g. Handelzalts, 2009) and is effective in improving instructors learning of pedagogies and skills in instructional design which in turn impact on their practices (Mishra et al., 2007).

Specifically, collaboration in TDTs that focuses on the uses of technology in educational practice contributes to professional learning about (i) technology and technology integration in teaching, (ii) (subject) content, (iii) course design, (iv) pedagogies and design of e-learning instruction and $(\mathrm{v})$ critical reflection. Through collaboration in TDTs, instructors acquire knowledge of e-learning technologies; they become positive about technology, develop competence on the use of e-learning technologies in teaching, and no longer avoid technology in their lessons (Mishra et al. 2007; Voogt et al. 2005, Voogt, 2010).

\section{Support for Teacher Design Teams}

TDTs provide a secure space in which instructors' creativity may flourish, and dialogue about teaching and learning by e-learning technology is reflected upon 
(Smolin, Lawless, Radinsky \& Newman, 2003). Supporting TDTs then becomes important because it makes instructors benefit more from the outcomes of interactions in such teams. The main kinds of supports that are offered to instructors during course design and delivery are (i) technological and (ii) pedagogical support (Mishra et al., 2007; Smolin et al., 2003; Sife, Lwoga \& Sanga, 2007; Waddoups et al, 2004). According to Sife et al. (2007), technical support for instructors in TDTs is an important part for their learning about e-learning course design and delivery. Instructors need support with installations of computers, accessories and software, maintenance, network administration, and security management (Bakari, Tarimo, Yngstrom \& Magnusson, 2005; Poumay, Dupont, Georges \& Leclercq, 2001).

Pedagogical support in design teams is necessary because most instructors feel difficulties in transferring their courses from traditional into e-learning courses (Bates, 2000; De Boer, 2004). According to Telnova (2005), a well-structured template with inbuilt instructional approaches is useful in supporting instructors during the design and organising of their courses and student activities in a learning management system.

There are different formats for organising support for instructors in TDTs (Bennett, Agostinho, Lockyer, Harper \& Lukasiak, 2007; Voogt et al., 2005; Voogt, 2010). Workshops blended with other strategies are one of the most useful formats for promoting professional learning by instructors (Voogt et al., 2005; Voogt, 2010), and are used for setting the scene and introductory activities. General meetings are another format of organising support for instructors in design teams (Handelzalts, 2009; Thousand \& Villa, 1993). Regularly convened general meetings bring instructors together for critical reflection and discussion of their experiences, challenges and opportunities related to the innovation they are working on. The general meetings format allows for provision of support to all instructors at once instead of concentrating attention upon individuals, and also assist in collaborations and support between instructors.

\section{Purpose of the study}

The purpose of the study reported in this article was to understand the impact of collaborative course design upon TDTs, towards promoting instructor professional development in e-learning course design. The main research question was: How did collaborative course design in TDTs contribute to instructors' professional learning? The following sub-questions guided the study:

1. How did instructors experience learning in TDTs?

2. What did instructors report to have learned from collaborative course design?

3. How did the support offered to the TDTs contribute to instructors' learning?

\section{Methods}

\section{Design of the study}

This study employed a multiple case study research design. Yin (2003) describes a case study research design as an appropriate method for investigating a particular phenomenon within its real-life context when the phenomenon and context are closely related. This was the case in this study as instructors' use of e-learning technologies at 
the Open University of Tanzania (OUT) is strongly influenced by their perceptions and constraints at the university. Two cases, namely the Faculty of Science, Technology \& Environmental Studies (FSTES) and the Institute of Continuing Education (ICE) were explored during the study. Instructors involved in the study were considered as units of analysis and OUT as the context of the study.

\section{Participants}

The participants were twelve instructors, eight from the Faculty of Science, Technology \& Environmental Studies (FSTES) and four from the Institute of Continuing Education (ICE). The instructors from FSTES were selected because they were involved in teaching courses which were identified by the faculty for conversion into e-learning courses. The four instructors from ICE were selected based on their interest in participating in the study and because they had basic computer applications skills. The 12 instructors (8 males, 4 females) formed 6 pairs of teams referred to as Teacher Design Teams (TDTs). All instructors were based in Dar es Salaam. Their average age was 37 years in FSTES and 41 in ICE respectively. Instructors had different teaching experiences though all had excellent computer and Internet skills.

\section{Instruments and data analysis}

Interview guides were used for data collection. The interview questions were: 'How did you find collaborative course design?', 'What challenges did you encounter when working in the design teams?', 'How did the professional development contribute to your professional growth?' and 'What kinds of support did you consider useful during course design?' Each instructor was interviewed face to face by the researcher three times: at the end of the two workshops and after course design.

A total of 36 interviews were collected, transcribed, and transported into Atlasi.Ti [http:/ / www.atlasti.com/]. Deductive and inductive approaches (Miles \& Huberman, 1994) were used to code the interview transcripts. Theoretical knowledge guided deductive coding, and focused on instructor satisfaction (e.g. confidence, clarity of the rationale, collaboration), challenges (e.g. time, narrow bandwith), contributions of collaborative course design (e.g. concrete procedures, interaction with students), pedagogical support (e.g. course design support, course delivery support) and technical support (e.g. installation, downloading, uploading). The inductive approach was used to refine the codes derived from theory and to identify sub-clusters that were not addressed in the literature, but appeared relevant in this study (e.g. seniority, limitations with offline Moodle, limited office space, insufficient allowance). Samples of interview responses of four instructors from each of the two workshops and from course design, together with a list of codes were re-coded by a colleague in the department. An inter-rater reliability, kappa $=.84(p=.000)$ was computed.

\section{Context for the current study}

The study reported in this article builds upon a previous study (Nihuka \& Voogt, $2011 b)$, which was conducted to explore the experiences of instructors with TDTs as a strategy to professional development. It also sought to understand students' experiences with redesigned courses and e-learning delivery. Nihuka \& Voogt (2011b) found that instructors were enthusiastic about working in the design team, and students were satisfied with the courses they accessed through an offline Moodle LMS (i.e. Moodle run on a local computer and not on a regionally networked server, as 
illustrated by Garrote, Petterson and Christie, 2011). Instructors benefited from collaboration in the design team because it enhanced their skills in course redesign for e-learning delivery, and helped them on how to support students during the course.

Despite favourable returns, instructors had several concerns, including (i) working in TDTs which is challenging and time demanding, and (ii) they needed more support in design teams. The current study dealt with these concerns in the following ways. First, the study integrated the programs of the introductory workshops and activities of design team with the schedules of instructors and the university almanac. Second, the study improved the support system by employing workshops and regular general meetings as a format for offering support to the design teams. And third, time was devoted during the workshops and general meetings to discuss how to use templates and the scope for using short text messages as an alternative to making phone calls

\section{Professional development}

\section{Professional development arrangement}

The arrangement involved introductory activities in two workshops and general meetings as a format for offering support to instructors during collaborative course design in TDTs. Two workshops were conducted; one before and the other after course redesign. In the first workshop lasting three hours, instructors were introduced to the course redesign process after which they worked in TDTs for 10 weeks to redesign their courses. It also prepared instructors for e-learning course design work, particularly on how to plan and write different materials for e-learning courses (e.g. preparing PowerPoint slides, searching resources, lesson notes, study materials, etc.). The workshop used presentations and demonstrations of exemplary e-learning courses that were developed during a pilot study (Voogt \& Nihuka, 2011b) to stimulate discussions on course design. Two instructors facilitated during the workshop. After the first workshop, instructors worked in design teams to redesign their courses. The emphasis was upon redesigning existing courses, rather than developing new ones. Five general meetings served for the design teams to discuss different challenges, issues and problems related to the course redesign process. Appropriate support was provided to the design teams in the general meetings. A final workshop lasting two hours was convened after all e-learning courses were developed, to discuss e-learning course delivery and how to use email and mobile phones to interact with students during the course. The redesigned courses were then delivered to students in the regional centres using offline Moodle LMS.

\section{Implementation of e-learning}

A total of 12 traditional distance education courses were redesigned into e-learning courses and uploaded into offline Moodle LMS. Because of students' limited access to computers (Nihuka \& Voogt, 2011a). we decided to use the computer laboratories in the regional centres of the OUT. In this way students' access to the courses was secured, although they still had to travel to the regional centres to access the e-learning courses. The 12 e-learning courses were installed in the computer laboratories at three regional centres, namely Dar es Salaam, Singida and Manyara. In each centre, all 12 courses were uploaded on a computer which was networked through a local area network to the rest of computers in the laboratory. This allowed convenient access to the courses by students from any computer within the regional centre. 
Students who took the redesigned courses from FSTES and ICE were given instruction on how to access courses and other learning resources in offline Moodle in their respective regional centres. The orientation focused on how to access courses and how to use email and mobile phones to interact with course instructors. The course duration was 12 weeks.

\section{Results}

\section{Instructors' experiences with TDTs}

When asked about their experiences with collaborative course design in TDTs for their learning, instructors reported that they were satisfied with the approach. The results in Table 1 indicate five sub-clusters that were identified in the data and that the instructors considered as strengths of TDTs: clarity of the rationale, potential of elearning technologies and knowledge, improvement of confidence, promotion of confidence and collaboration.

Table 1: Instructors' opinion about the strengths of TDTs

\begin{tabular}{|c|c|c|c|c|c|c|c|c|c|c|c|c|}
\hline \multirow{3}{*}{ Satisfaction } & \multicolumn{8}{|c|}{$\begin{array}{c}\text { Faculty of Science, Technology \& } \\
\text { Environmental Studies (FSTES), }(\mathrm{n}=8)\end{array}$} & \multicolumn{4}{|c|}{$\begin{array}{l}\text { Institute of Continuing } \\
\text { Education (ICE), }(\mathrm{n}=4)\end{array}$} \\
\hline & \multicolumn{2}{|c|}{ TDT 1} & \multicolumn{2}{|c|}{ TDT 2} & \multicolumn{2}{|c|}{ TDT 3} & \multicolumn{2}{|c|}{ TDT 4} & \multicolumn{2}{|c|}{ TDT 5} & \multicolumn{2}{|c|}{ TDT 6} \\
\hline & T1 & $\mathrm{T} 2$ & T3 & T4 & T5 & T6 & T7 & $\mathrm{T} 8$ & T9 & T10 & T11 & T12 \\
\hline Clarity of the rationale & $\sqrt{ }$ & $\sqrt{ }$ & $\sqrt{ }$ & $\sqrt{ }$ & $\sqrt{ }$ & $\sqrt{ }$ & $\sqrt{ }$ & $\sqrt{ }$ & $\sqrt{ }$ & $\sqrt{ }$ & $\sqrt{ }$ & $\sqrt{ }$ \\
\hline $\begin{array}{l}\text { Potentials of e-learning } \\
\text { technologies }\end{array}$ & $\sqrt{ }$ & $\sqrt{ }$ & $\sqrt{ }$ & $\sqrt{ }$ & $\sqrt{ }$ & $\sqrt{ }$ & $\sqrt{ }$ & $\sqrt{ }$ & $\sqrt{ }$ & $\sqrt{ }$ & $\sqrt{ }$ & $\sqrt{ }$ \\
\hline $\begin{array}{l}\text { Improvement of } \\
\text { confidence }\end{array}$ & $\sqrt{ }$ & $\sqrt{ }$ & & & $\sqrt{ }$ & $\sqrt{ }$ & $\sqrt{ }$ & $\sqrt{ }$ & $\sqrt{ }$ & $\sqrt{ }$ & & \\
\hline $\begin{array}{l}\text { Promotion of } \\
\text { competence }\end{array}$ & $\sqrt{ }$ & $\sqrt{ }$ & $\sqrt{ }$ & $\sqrt{ }$ & $\sqrt{ }$ & $\sqrt{ }$ & $\sqrt{ }$ & $\sqrt{ }$ & $\sqrt{ }$ & $\sqrt{ }$ & $\sqrt{ }$ & $\sqrt{ }$ \\
\hline Collaboration & $\sqrt{ }$ & $\sqrt{ }$ & $\sqrt{ }$ & $\sqrt{ }$ & $\sqrt{ }$ & $\sqrt{ }$ & $\sqrt{ }$ & $\sqrt{ }$ & $\sqrt{ }$ & $\sqrt{ }$ & $\sqrt{ }$ & $\sqrt{ }$ \\
\hline
\end{tabular}

Note: TDT $=$ Teacher design team; T1-T12 = Teachers 1-12; $\sqrt{=}$ aspects instructors reported as a strength of TDTs

All instructors found TDTs satisfactory because they provided an opportunity for discussions which contributed to the clarity of the rationale for e-learning implementation. According to instructors, the discussions improved their awareness of the reasons for using e-learning as testified for example by $\mathrm{T} 1$ :

The discussion about the reasons for e-learning integration in teaching was one of the strong points of the program. Before professional development I didn't see a reason why I should consider using technologies in teaching of my courses. I feel that technologies can be one of the solutions to some of the challenges I find during teaching of my course (T1, Interview 1).

All instructors were also satisfied with TDTs, because it promoted awareness of the potential of e-learning technologies and how to use them for communication with students. A comment from T3 exemplifies the opinions of the instructors:

The training enlightened me about the potential of Moodle technology as an answer to the challenges of drop out, lack of regular communication, poor achievement of students, etc, which comes with dependence on traditional Open and Distance Learning mode.... and it created opportunity for discussions and sharing ideas with colleagues about the potential of e-learning technologies... I think I can use emails for communication with students in my courses (T3, Interview 1). 
Six instructors from FSTES and two instructors from ICE mentioned that TDTs improved their confidence in course redesign and in using Moodle as illustrated in the following statement:

I liked the idea of designing courses in teams. I found it interesting and it provided me confidence in being able to modify my course according to the template we agreed upon. I feel am confident enough to design my course and use Moodle to facilitate teaching (T4, Interview 1).

All instructors were satisfied with TDTs because it promoted their competence in using technologies for (i) communication and (ii) delivery of courses and resources. TDTs also promoted instructors' competence in using technologies for providing feedback to students.

Last but not least instructors appreciated TDTs, because of collaboration. All instructors pointed out that collaboration promoted confidence and created a favorable environment for course redesign, generated ideas on how to deal with students email, how to organise course content and ideas about when to provide feedback to students. One of the instructors expressed his feelings as follows:

Collaboration [learning from each other and supporting each other in an informal way] ensured confidence to continue with course design task. I found this useful especially when discussing how to compose student activities, when to design courses and how to handle students' email and messages.... it provided a relaxed atmosphere which I found useful for the task of designing courses. .... it was also useful for exchanging ideas such as how to organise content in the template, student support, and kind of activities to be included and ways for providing feedback to students (T6, Interview 2).

\section{Instructors' experiences with TDTs: Challenges}

The instructors mentioned a number of challenges encountered when working in TDTs. These challenges are presented in Table 2 and illustrated in quotations derived from the interviews.

Table 2: Challenges encountered by instructors in TDTs

\begin{tabular}{|c|c|c|c|c|c|c|c|c|c|c|c|c|}
\hline \multirow{3}{*}{ Challenges } & \multicolumn{8}{|c|}{$\begin{array}{c}\text { Faculty of Science, Technology \& } \\
\text { Environmental Studies (FSTES), }(\mathrm{n}=8)\end{array}$} & \multicolumn{4}{|c|}{$\begin{array}{l}\text { Institute of Continuing } \\
\text { Education (ICE), }(n=4)\end{array}$} \\
\hline & \multicolumn{2}{|c|}{ TDT 1} & \multicolumn{2}{|c|}{ TDT 2} & \multicolumn{2}{|c|}{ TDT 3} & \multicolumn{2}{|c|}{ TDT 4} & \multicolumn{2}{|c|}{ TDT 5} & \multicolumn{2}{|c|}{ TDT 6} \\
\hline & $\mathrm{T} 1$ & $\mathrm{~T} 2$ & T3 & $\mathrm{T} 4$ & T5 & T6 & T7 & T8 & T9 & T10 & T11 & T12 \\
\hline Time & & $\sqrt{ }$ & & & $\sqrt{ }$ & $\sqrt{ }$ & $\sqrt{ }$ & & $\sqrt{ }$ & & & $\sqrt{ }$ \\
\hline $\begin{array}{l}\text { Power cuts and } \\
\text { unreliability }\end{array}$ & $\sqrt{ }$ & $\sqrt{ }$ & $\sqrt{ }$ & $\sqrt{ }$ & $\sqrt{ }$ & $\sqrt{ }$ & $\sqrt{ }$ & $\sqrt{ }$ & $\sqrt{ }$ & $\sqrt{ }$ & $\sqrt{ }$ & $\sqrt{ }$ \\
\hline Narrow bandwidth & $\sqrt{ }$ & $\sqrt{ }$ & $\sqrt{ }$ & $\sqrt{ }$ & $\sqrt{ }$ & $\sqrt{ }$ & $\sqrt{ }$ & $\sqrt{ }$ & $\sqrt{ }$ & $\sqrt{ }$ & $\sqrt{ }$ & $\sqrt{ }$ \\
\hline $\begin{array}{l}\text { Seniority (difference } \\
\text { in academic rank) }\end{array}$ & & & & & & & & $\sqrt{ }$ & & & & \\
\hline $\begin{array}{l}\text { Unfamiliarity between } \\
\text { instructors }\end{array}$ & & & $\sqrt{ }$ & & & & & & & & & \\
\hline $\begin{array}{l}\text { Limitations of offline } \\
\text { Moodle system }\end{array}$ & $\sqrt{ }$ & $\sqrt{ }$ & $\sqrt{ }$ & $\sqrt{ }$ & $\sqrt{ }$ & $\sqrt{ }$ & $\sqrt{ }$ & $\sqrt{ }$ & $\sqrt{ }$ & $\sqrt{ }$ & $\sqrt{ }$ & $\sqrt{ }$ \\
\hline $\begin{array}{l}\text { Limited office space } \\
\text { and access }\end{array}$ & $\sqrt{ }$ & $\sqrt{ }$ & $\sqrt{ }$ & $\sqrt{ }$ & $\sqrt{ }$ & $\sqrt{ }$ & $\sqrt{ }$ & $\sqrt{ }$ & $\sqrt{ }$ & $\sqrt{ }$ & $\sqrt{ }$ & $\sqrt{ }$ \\
\hline Insufficient allowance & & $\sqrt{ }$ & $\sqrt{ }$ & $\sqrt{ }$ & $\sqrt{ }$ & & & & $\sqrt{ }$ & & $\sqrt{ }$ & \\
\hline
\end{tabular}

Note: TDT = Teacher design team; T1-T12 = Teachers 1-12; $\sqrt{ }=$ challenges reported by teachers. 
Six instructors indicated time as a challenge for TDTs. Time was reported in two perspectives. In the first perspective, instructors felt that the actual time for the workshops was actually short and they required more time. T10 expressed his concerns as follows:

The professional development [workshops] was too short for me because everything was done only in one day. I think this is why certain topics were not discussed in detailed, e.g. a topic on theoretical understanding of design teams which was done in a hurry. I could benefit more if we had it for at least 5 full days. This could allow more time to explore and discuss the details on how to design courses. I think this could make us more comfortable and skilful (T10, Interview 1).

In the second perspective, instructors stated that collaborating in TDTs was time consuming because of too many demanding university routines. The following statement by $\mathrm{T} 5$ is an example:

I found collaborative course design so time demanding because of the busy schedule at the university. We are already loaded with invigilation of examinations, marking, and supervision of teaching practices and field training. It was difficult for me to meet and work with my colleague in the team on regular bases (T5, Interview 2).

As a way of dealing with the situation, the majority of instructors pointed out that they redesigned their courses during out of office hours and shared their courses to colleagues in general meetings and in respective teams, as evidenced in the following statement:

Getting time from busy routine to work in design team was a big challenge. However, I learned from colleagues during one of the general meetings that I can do my work [in the evening or night] after the supervision of field practices, face to face or teaching practice; I find hard maintaining it but it worked in some days by sacrificing other things (T3, Interview 2).

Power cuts and unreliability in the electricity supply and narrow bandwidth were experienced as a challenge by all instructors. It hampered the writing of courses, the uploading of courses and resources into Moodle and handling email. When there was a power cut, they had to wait until there was electricity and an improved Internet signal.

Seniority (difference in academic rank) was reported by one instructor (T8) as one of the challenges of working in TDTs. T8 explained that she felt she could learn more (about course design and delivery) from discussions than just listening to long stories of a more senior colleague. Specifically, she stated that:

\footnotetext{
I found it difficult and uncomfortable for me to collaborate (work together) with a more senior colleague in our team because he was so senior to me and was higher in rank and designing a course for the first time was already a challenging activity for me. He was giving too long explanations over issues and I felt uncomfortable to criticise or whatever. I found myself listening more than discussing. I think I could learn more through dialogue as colleagues than just listening to one person (T8, Interview 2).
}

In another situation, results show that one instructor (T3) reported that working with an unfamiliar colleague in a team was a challenge, as he explained:

I found working in a team with an unfamiliar colleague as a challenging moment for me especially at the beginning (T3, Interview 2). 
Instructors in all TDTs expressed concerns about the limitations of the offline Moodle LMS. Instructors explained that offline Moodle was inflexible in space and time and that it required them to come to their office or to a computer laboratory to access or update courses and resources. Lack of personal office space was a challenge to all instructors when working in TDTs, particularly because they shared an office with 1-2 other colleagues, which caused limited access to computers and the Internet. One of the instructors (T7) indicated that he had to come to his office quite early on some days in order to conveniently use the computer and Internet facilities.

Last but not least, the results indicated that half of the instructors complained about the allowance provided to instructors for transport. When asked for suggestions, instructors suggested that the allowance should be increased (without suggesting an amount) in order to motivate instructors for the training. One of the instructors had the following to say:

The allowance was not adequate.... The researcher should consider increasing the amount next time for instructors so that we are motivated to work (T9, Interview 1).

\section{Contribution of collaborative course design to instructors' professional learning}

One specific question in the interview guide addressed the contribution of collaborative course design in TDTs to instructors' professional learning. Table 3 presents instructors' perception on this issue.

Table 3: Contribution of collaborative course design to instructors' professional learning

\begin{tabular}{|c|c|c|c|c|c|c|c|c|c|c|c|c|c|}
\hline & \multirow{3}{*}{$\begin{array}{l}\text { Aspects of } \\
\text { professional } \\
\text { learning }\end{array}$} & \multicolumn{8}{|c|}{$\begin{array}{l}\text { Faculty of Science, Technology \& } \\
\text { Environmental Studies (FSTES), }(n=8)\end{array}$} & \multicolumn{4}{|c|}{$\begin{array}{l}\text { Institute of Contin- } \\
\text { uing Education } \\
(\mathrm{ICE}),(n=4)\end{array}$} \\
\hline & & \multicolumn{2}{|c|}{ TDT 1} & \multicolumn{2}{|c|}{ TDT 2} & \multicolumn{2}{|c|}{ TDT 3} & \multicolumn{2}{|c|}{ TDT 4} & \multicolumn{2}{|c|}{ TDT 5} & \multicolumn{2}{|c|}{ TDT 6} \\
\hline & & $\mathrm{T} 1$ & T2 & T3 & $\mathrm{T} 4$ & T5 & T6 & T7 & T8 & T9 & T10 & T11 & T12 \\
\hline \multirow{3}{*}{$\begin{array}{l}\text { Course } \\
\text { design }\end{array}$} & Concrete procedures & $\sqrt{ }$ & $\sqrt{ }$ & $\sqrt{ }$ & $\sqrt{ }$ & $\sqrt{ }$ & $\sqrt{ }$ & $\sqrt{ }$ & $\sqrt{ }$ & $\sqrt{ }$ & $\sqrt{ }$ & $\sqrt{ }$ & $\sqrt{ }$ \\
\hline & $\begin{array}{l}\text { Preparation of } \\
\text { PowerPoint slides }\end{array}$ & $\sqrt{ }$ & & & & $\sqrt{ }$ & & & & $\sqrt{ }$ & $\sqrt{ }$ & $\sqrt{ }$ & $\sqrt{ }$ \\
\hline & Use of templates & $\sqrt{ }$ & $\sqrt{ }$ & & & $\sqrt{ }$ & $\sqrt{ }$ & & & $\sqrt{ }$ & $\sqrt{ }$ & $\sqrt{ }$ & $\sqrt{ }$ \\
\hline \multirow[t]{2}{*}{$\begin{array}{l}\text { Course } \\
\text { delivery }\end{array}$} & $\begin{array}{l}\text { Use Moodle system in } \\
\text { course delivery }\end{array}$ & $\sqrt{ }$ & $\sqrt{ }$ & $\sqrt{ }$ & $\sqrt{ }$ & $\sqrt{ }$ & $\sqrt{ }$ & $\sqrt{ }$ & $\sqrt{ }$ & $\sqrt{ }$ & $\sqrt{ }$ & $\sqrt{ }$ & $\sqrt{ }$ \\
\hline & $\begin{array}{l}\text { When to interact with } \\
\text { students by emails } \\
\text { and mobile phones }\end{array}$ & $\sqrt{ }$ & $\sqrt{ }$ & $\sqrt{ }$ & $\sqrt{ }$ & $\sqrt{ }$ & $\sqrt{ }$ & $\sqrt{ }$ & $\sqrt{ }$ & $\sqrt{ }$ & $\sqrt{ }$ & $\sqrt{ }$ & $\sqrt{ }$ \\
\hline
\end{tabular}

Note: TDT $=$ Teacher design team; T1-T12 = Teachers 1-12. $\sqrt{ }=$ contribution of collaborative course design on professional learning as reported by teachers.

Results in Table 3 indicate that all instructors explained that through their participation in TDTs they have concrete procedures at their disposition which they can follow during e-learning course design. A comment by one of the instructors was:

I feel I benefited from the workshop and working in TDTs because the training provided specific procedures on how to design traditional courses into e-learning courses. There was also a support system set to go for. These, together with the templates discussed during the workshops contributed to my learning about course design using the procedures (T10, Interview 2). 
Most instructors in FSTES already had knowledge of PowerPoint preparation before working in TDTs, but two instructors in FSTES and all instructors in ICE reported that they learned how to prepare PowerPoint slides for their e-learning courses in TDTs. Eight instructors reported that they benefited from using templates in organising their e-learning courses. According to one of the instructors (T11), the templates that were provided in the TDTs guided them to design their courses and helped them to transform traditional courses into e-learning courses:

I found the templates useful. They were specific and guided me when designing my print based course into e-learning course and this together with the regular support from the technical staff, helped me learn how to transform a course into e-learning course (T11, Interview 3).

All instructors shared the experience that working in TDTs also contributed to their knowledge and skills in using Moodle LMS for course delivery and agreed that working in TDTs contributed to knowledge about when to interact with students through email and short text messages. In addition, results indicate that the knowledge they gained helped instructors develop a more positive perception about email and mobile phones:

The discussions in the teams were helpful for me. I learned about when to provide feedback to students during the course. I never thought about using emails and messages to communicate with students for various purposes. I use emails to communicate with friends and relatives but never thought of using it in teaching like I did during the delivery of my course (T9, Interview 3 ).

\section{Pedagogical support contributing to instructors' learning}

The teachers received pedagogical and technical support in the professional development arrangement. Table 4 presents the pedagogical support that was reported useful for instructors during course design.

Table 4: Pedagogical support

\begin{tabular}{|c|c|c|c|c|c|c|c|c|c|c|c|c|c|}
\hline \multirow{3}{*}{\multicolumn{2}{|c|}{$\begin{array}{l}\text { Kinds of } \\
\text { support }\end{array}$}} & \multicolumn{8}{|c|}{$\begin{array}{c}\text { Faculty of Science, Technology \& } \\
\text { Environmental Studies (FSTES), }(\mathrm{n}=8)\end{array}$} & \multicolumn{4}{|c|}{$\begin{array}{l}\text { Institute of Continu } \\
\text { ing Education (ICE) } \\
\qquad(\mathrm{n}=4)\end{array}$} \\
\hline & & \multicolumn{2}{|c|}{ TDT 1} & \multicolumn{2}{|c|}{ TDT 2} & \multicolumn{2}{|c|}{ TDT 3} & \multicolumn{2}{|c|}{ TDT 4} & \multicolumn{2}{|c|}{ TDT 5} & \multicolumn{2}{|c|}{ TDT 6} \\
\hline & & T1 & $\mathrm{T} 2$ & T3 & $\mathrm{T} 4$ & T5 & T6 & $\mathrm{T} 7$ & T8 & T9 & T10 & T11 & T12 \\
\hline \multirow{6}{*}{$\begin{array}{l}\text { How to } \\
\text { design } \\
\text { courses }\end{array}$} & Content identification & $\sqrt{ }$ & & & & $\sqrt{ }$ & & & & $\sqrt{ }$ & & & \\
\hline & Prepare student activities & $\sqrt{ }$ & $\sqrt{ }$ & & $\sqrt{ }$ & $\sqrt{ }$ & $\sqrt{ }$ & $\sqrt{ }$ & $\sqrt{ }$ & & & $\sqrt{ }$ & \\
\hline & Prepare PowerPoint slides & $\sqrt{ }$ & & & & $\sqrt{ }$ & & & & $\sqrt{ }$ & $\sqrt{ }$ & $\sqrt{ }$ & $\sqrt{ }$ \\
\hline & $\begin{array}{l}\text { Convert study materials } \\
\text { into electronic lectures }\end{array}$ & & $\sqrt{ }$ & & $\sqrt{ }$ & & $\sqrt{ }$ & $\sqrt{ }$ & & $\sqrt{ }$ & $\sqrt{ }$ & $\sqrt{ }$ & $\sqrt{ }$ \\
\hline & $\begin{array}{l}\text { Use templates to organise } \\
\text { courses }\end{array}$ & $\sqrt{ }$ & $\sqrt{ }$ & $\sqrt{ }$ & $\sqrt{ }$ & & & $\sqrt{ }$ & $\sqrt{ }$ & $\sqrt{ }$ & $\sqrt{ }$ & $\sqrt{ }$ & $\sqrt{ }$ \\
\hline & $\begin{array}{l}\text { Use and navigate in } \\
\text { Moodle LMS }\end{array}$ & & & & & & & $\sqrt{ }$ & & $\sqrt{ }$ & $\sqrt{ }$ & $\sqrt{ }$ & $\sqrt{ }$ \\
\hline \multicolumn{2}{|c|}{$\begin{array}{l}\text { Timely response to students } \\
\text { email/ requests }\end{array}$} & $\sqrt{ }$ & & $\sqrt{ }$ & $\sqrt{ }$ & & $\sqrt{ }$ & $\sqrt{ }$ & & & $\sqrt{ }$ & $\sqrt{ }$ & $\sqrt{ }$ \\
\hline \multicolumn{2}{|c|}{$\begin{array}{l}\text { When to use email and mobile } \\
\text { phones to send feedback }\end{array}$} & $\sqrt{ }$ & $\sqrt{ }$ & $\sqrt{ }$ & $\sqrt{ }$ & $\sqrt{ }$ & $\sqrt{ }$ & $\sqrt{ }$ & $\sqrt{ }$ & & $\sqrt{ }$ & $\sqrt{ }$ & $\sqrt{ }$ \\
\hline
\end{tabular}

Note: TDT = Teacher design team; T1-T12 = Teachers 1-12; $\sqrt{=}$ pedagogical support teachers found useful. 
Regarding the support on course content identification, three instructors pointed out that the support was useful and contributed to their learning about how to identify resources and things to consider for developing e-learning courses. For example, T1 said:

... the support during course design and in the general meetings on how to identify content for the course were useful, it made me learn and become aware of how and what to consider during course design to develop my course. These made me competent in getting my course redesigned on time (T1, Interview 2).

A couple of instructors did not require the support on content identification. They pointed out several reasons. Some felt conversant in content identification because of their background in education (T8, T9, T11 and T12), others mentioned that TDTs and general meetings were time consuming (T4, T6 and T7), and they lacked time to participate in the meetings (T8). Eight instructors, most from FSTES, found the support offered to the design teams on how to construct and organise students' activities in e-learning courses useful. An illustrative answer from T1 was:

I found the support useful, together with the collaborations in teams and meetings, I learned how to formulate and organise students' activities during course design process. I found it even more very useful especially when designing students' activities myself (T1, Interview 1).

Furthermore, all instructors from ICE and two from FSTES mentioned that the support on how to prepare PowerPoint slides for inclusion in the e-learning courses enhanced their learning to prepare slides for their courses. The rest of instructors in FSTES indicated that they did not require support on PowerPoint preparation because they felt they had the needed skills.

Half of the instructors from FSTES and all instructors from ICE appreciated the support related to the conversion of printed study materials into electronic lectures for the e-learning courses, as evidenced by T4:

I found the support offered during general meetings as interesting and useful because I learned how to summarise lectures from printed study materials for inclusion in the e-learning course. This support enhanced competence on how to make summary of the lectures from printed study materials (T4, Interview 2).

Moreover, interview data showed that all instructors except two found the support on how to use templates to organise courses also useful. They indicated that the support helped them to learn a systematic approach:

...The support on a systematic course design and use of template to organise a course was useful for me. I feel that the competence that I acquired from using a template helped me to organise my e-learning course in the given template (T8, Interview 2).

All four instructors from ICE and one instructor from FSTES reported that the support on the use of Moodle and navigation in the system was also useful. According to the instructors the support sharpened their understanding about how to use Moodle and how to navigate through the system for checking students' emails and other things. Results show that majority of instructors in FSTES did not require support on how to use Moodle and navigation in the system. However, the concern for majority of instructors was that the offline Moodle system: 
... did not address the problems of location/space and time because it required students to visit Regional Centre offices or headquarters to access the courses.... access to emails was sometimes affected by power fluctuations, regular power cuts and slow Internet speed (T3, Interview 4).

Eight instructors appreciated the support in terms of the ideas about when to respond to students' email and requests. The instructors stated that they learned about the need to respond to students on time to avoid discouragement:

... the support enhanced my knowledge about the need to respond to students mails on time so that they are not discouraged by delayed responses. I learned about when to support students by responding to their emails and also about when to write them encouragement emails particularly at the beginning of the course because they required regular explanations on how to access courses in Moodle (T11, Interview 4).

Except for one, all instructors shared the opinion that the support on when to use emails and mobile phones to send feedback to students during the course was useful. They clarified that the support helped them learn about how to write more focused feedback to students (T5) and how to deal with bulky emails by composing a collective email to students (T3). As T3 puts it:

I liked the support on how to deal with bulk of students' emails, the support helped me learn more about how to compose collective emails to students when writing feedback (T3, Interview 4).

\section{Technical support contributing to instructor learning}

The technical support that teachers found useful during course design is presented in Table 5 .

Table 5: Technical support

\begin{tabular}{|c|c|c|c|c|c|c|c|c|c|c|c|c|}
\hline \multirow{3}{*}{$\begin{array}{l}\text { Kinds of } \\
\text { support }\end{array}$} & \multicolumn{8}{|c|}{$\begin{array}{c}\text { Faculty of Science, Technology \& } \\
\text { Environmental Studies (FSTES), }(n=8)\end{array}$} & \multicolumn{4}{|c|}{$\begin{array}{l}\text { Institute of Continuing } \\
\text { Education (ICE), }(n=4)\end{array}$} \\
\hline & \multicolumn{2}{|c|}{ TDT 1} & \multicolumn{2}{|c|}{ TDT 2} & \multicolumn{2}{|c|}{ TDT 3} & \multicolumn{2}{|c|}{ TDT 4} & \multicolumn{2}{|c|}{ TDT 5} & \multicolumn{2}{|c|}{ TDT 6} \\
\hline & T1 & T2 & T3 & $\mathrm{T} 4$ & T5 & T6 & $\mathrm{T}$ & $\mathrm{T \varepsilon}$ & $\mathrm{T}$ & $\mathrm{T}$ & 11 & T12 \\
\hline Installation of Moodle & $\sqrt{ }$ & $\sqrt{ }$ & $\sqrt{ }$ & $\sqrt{ }$ & $\sqrt{ }$ & $\sqrt{ }$ & $\sqrt{ }$ & $\sqrt{ }$ & $\mathrm{v}$ & $\mathrm{v}$ & $\sqrt{ }$ & $\sqrt{ }$ \\
\hline $\begin{array}{l}\text { Searching and down- } \\
\text { loading resources }\end{array}$ & & $\sqrt{ }$ & $\sqrt{ }$ & & $\sqrt{ }$ & & & & $\mathrm{v}$ & $\mathrm{v}$ & $\sqrt{ }$ & $\sqrt{ }$ \\
\hline $\begin{array}{l}\text { Uploading of resources } \\
\text { in Moodle LMS }\end{array}$ & $\sqrt{ }$ & & & & & & $\sqrt{ }$ & & $\sqrt{ }$ & v & $\sqrt{ }$ & $\sqrt{ }$ \\
\hline $\begin{array}{l}\text { Updating resources in } \\
\text { Moodle LMS }\end{array}$ & & & $\sqrt{ }$ & $\sqrt{ }$ & $\sqrt{ }$ & & & & $\sqrt{ }$ & v & $\sqrt{ }$ & $\sqrt{ }$ \\
\hline Virus problems & & & & & & & $\sqrt{ }$ & & $\sqrt{ }$ & $v$ & $\sqrt{ }$ & $\sqrt{ }$ \\
\hline $\begin{array}{l}\text { Internet connection } \\
\text { problems }\end{array}$ & & & & & & & & $\sqrt{ }$ & $\sqrt{ }$ & $\sqrt{ }$ & $\sqrt{ }$ & $\checkmark$ \\
\hline
\end{tabular}

Note: TDT $=$ Teacher design team; T1-T12 = Teachers 1-12; $\sqrt{=}$ technical support teachers found useful.

Results indicate that instructors in all teams found the support for installation of Moodle helpful. The support helped to avoid frustrations during course design and that it made them persist in the course design task. This was illustrated by the following comment from one of the instructors: 
The support on the installation of Moodle in my computer was very useful because then I was able to continue with course design task. The helped to avoid frustrations during course design and made me experience the course design process more (T2, Interview 2).

All instructors from ICE and three from FSTES reported that the support on how to search and download resources from the Internet was also useful. Specifically, they expressed that the support contributed to their learning of suitable search strategies to use during course design. They also learned how to retrieve relevant resources from the Internet for different aspects of their courses.

Results in Table 5 reveal that the majority of instructors in the FSTS did not require support on how to upload resources to the Moodle LMS. FSTS instructors explained that they had knowledge on how to deal with most technical problems and that they did not encounter any serious problem as indicated in this statement:

I personally did not require support of any kind during course delivery because I have knowledge of how to deal with most technical problems. And I did not encounter any serious teaching problem (T2, Interview 3).

However, all instructors in ICE found the support on how to upload resources to the Moodle LMS quite useful. They felt that the support helped them benefit professionally as illustrated in the following response:

The support was useful to a greater extent. The support and discussions on how to develop a course bit by bit and on how to upload the entire course in the Moodle were helpful. The support contributed to my professional learning about course design; in fact the general meetings helped me catch up with my colleagues because sometimes I missed working in my team. The only challenges were; it was time demanding to attend general meetings and sometimes people were not focused in some of the meetings (T9, Interview 2).

The support on how to update resources in the Moodle LMS was reported useful by all instructors in ICE but only three instructors from FSTES (T 3, T4 \& T5). The support enhanced instructors' knowledge of how to add or remove documents in Moodle. Besides, results show that compared to their counterparts in ICE, instructors in FSTES (except T7) did not require support related to fixing virus-related problems. According to the instructors in ICE, the support avoided frustrations and made them enjoy using Moodle during course delivery.

Also, results reveal that instructors in FSTES did not require support on Internet connection problems, which was reported useful by all instructors in ICE. One of the instructors in ICE shared that:

... the support was relevant because it addressed problems that I encountered during e-learning course delivery, such as Internet connections, downloading of articles for students and writing of collective emails to students" (T12, Interview 4).

Besides the perceived usefulness of technical support, two major challenges were reported by instructors which related to (i) presence of few technicians (i.e. only 2) (T10, Interview 2) and (ii) unavailability of the technical staff especially when engaged in other duties (T3 \& T4, Interview 2). Instructors suggested that:

... there should be a technical staff in each faculty / institute to provide support to the instructors on technical problems because without it course design and delivery by elearning technologies can become too difficult task to accomplish (T8, Interview 2). 


\section{Discussion and conclusions}

The study reported in this article investigated the impact of a collaborative course design strategy in promoting instructors' professional development for e-learning course design and delivery at the Open University of Tanzania. Results suggest, that despite challenges, the instructors were positive about this professional development strategy. The strategy helped instructors to transform their print based courses into elearning courses and to use Moodle LMS to deliver courses to students. These results are consistent with other studies that use collaborative design by instructors as a strategy to implement curriculum innovations (e.g. Garrote, Petterson \& Christie, 2011; Mishra et al., 2007; Uys, 2010; Voogt, 2010). The combination of a bottom up strategy with support from top management and facilitated by the researcher, as was applied in this study, was similar to the experiences of Uys (2010) in the context of Australia.

Instructors were satisfied about their experience with collaborative course design and were clear about its strength in supporting the implementation of e-learning. Through the strategy, instructors acquired knowledge about potential of e-learning technologies and rationale for using them. According to Walker \& Johnson (2008), such knowledge contributes to instructors' decision to consider using e-learning in their courses. Moreover, the strategy promoted instructors' confidence and competencies in course design.

Consistent with previous studies (e.g. Desimone et al., 2002; Mishra et al., 2007; Voogt, 2010), instructors learned several skills during collaborative course design, which included the use of templates and concrete procedures which they can follow during e-learning course design. They also learned how to prepare PowerPoint slides, how to use Moodle, and they were able to decide the right time to interact with students using email and mobile phones. Instructors developed competencies and confidence in using e-learning technologies such Moodle and email. This is likely to contribute to improved practices (Mishra et al., 2007) and lead to implementation of e-learning and improved academic outcomes for students (Nihuka, 2011).

The pedagogical and technical support offered during collaborative course design contributed to the positive perception by instructors of the effectiveness of the strategy on their professional development. However, this study also showed that the kind of support that instructors required was to a greater extent influenced by their science or education backgrounds. Without support, instructors found it difficult to transform their courses into e-learning courses (Bates, 2000) and would probably result in less impact on instructors' professional development.

Instructors encountered several challenges during course design and delivery. There were challenges due to power cuts and limited access to computers and the Internet as indicated in Nihuka \& Voogt (2011a). However, although the challenge of power cuts persisted, the situation with access to computers and the Internet has improved compared to the situation reported in Nihuka (2008). Slow Internet speeds due to narrow bandwidth and the inflexibility of offline Moodle LMS were also of concern to the instructors. Perhaps the initiative to connect the national research and educational networks in Africa to the global research and education network community (GÉANT) in Europe (Mbwette, 2008) will improve the current bandwidth. Otherwise, this study demonstrated the potential of offline systems such as offline Moodle LMS for bandwidth-challenged sub-Saharan African countries. Offline Moodle LMS allowed 
easier access to course outlines and learning resources for students in the Regional Centres. Similar findings were given in Garrote et al. (2011).

A few reactions of instructors to TDTs, such as seniority, allowances and financial incentives, probably refer to cultural aspects that are sensitive to the concept of collaborative design in TDTs. Gervedink Nijhuis (2012) in her study about professional development arrangements in higher education in Ghana observed similar tensions in the implementation of professional development strategies that have a basis in the Western literature.

Results discussed in this article may not be generalised across universities in subSaharan Africa because of their diversity. A knowledge of specific contexts and needs is necessary for successful implementation of e-learning technologies in education. Above all, supporting instructors towards e-learning integration through collaborative course design is a learning experience for both researcher and instructors. More research is needed on how to use collaborative course design as a strategy to promote e-learning implementation in education in the context of sub-Saharan Africa. Unlike traditional workshops and seminars, collaborative course design with careful designed support is effective in promoting instructors' professional development related to elearning course design and delivery. The impact of collaborative course design on students' academic outcomes from e-learning is reported elsewhere (Nihuka, 2011).

\section{References}

Aguti, J. N. \& Fraser, W. J. (2006). Integration of information communication technologies (ICTs) in the distance education bachelor of education programme, Makerere University, Uganda. Turkish Online Journal of Distance Education, 7(3), 89-104. https: / / tojde.anadolu.edu.tr/tojde23/pdf/article_7.pdf

Bakari, J. K., Tarimo, C. N., Yngstrom, L. \& Magnusson, C. (2005). State of ICT security management in the institutions of higher learning in developing countries: Tanzania case study. Paper presented at the Fifth IEEE International Conference on Advanced Learning Technologies (ICALT'05). http: / / dx.doi.org/10.1109/ICALT.2005.243

Bates, A. W. (2000). Managing technological change: Strategies for college and university leaders. San Francisco: Jossey-Bass.

Bennett, S., Agostinho, S., Lockyer, L., Harper, B. \& Lukasiak, J. (2007). Supporting university teachers create pedagogically sound learning environment using learning designs and learning objects. IADIS International Journal, 4(1), 16-26. http: / / www.iadis.net/dl/final_uploads / 2006410102.pdf

Borko, H. (2004). Professional development and teacher learning: Mapping the terrain. Educational Researcher, 33(8), 3-15. http: / / dx.doi.org/10.3102/0013189X033008003

De Boer, W. (2004). Flexibility support for a changing university. Doctoral Thesis, University of Twente, Enschede. http: / / doc.utwente.nl/41410/1/DissertatieWdeBoerITBE.pdf

Desimone, L. M., Porter, A. C., Garet, M. S., Yoon, K. S. \& Birman, B. F. (2002). Effects of professional development on teachers' instruction: Results from a three-year longitudinal study. Educational Evaluation and Policy, 24(2), 81-112. http: / / dx.doi.org/10.3102/01623737024002081

Dzakiria, H. (2004). Technology does not always teach distance learners, but effective distance teachers do. Malaysian Online Journal of Instructional Technology, 1(1), 60-81. http: / / pppjj.usm.my / mojit/articles / pdf/ 0804/ Technology\% 20Does\%20Not\%20Always\%2 0Teach $\% 20$ Distance $\% 20$ Learners.pdf 
Gakio, K. (2006). African tertiary institutions connectivity survey. Report commissioned by the International Development Research Centre of Canada. [viewed 20 Sep 2009; verified 29 Feb 2012]. http:/ / www.aau.org/renu/docs/ATICS2006.pdf

Garrote, R., Petterson, T. \& Christie, M. (2011). LiveUSB Mediated Education: A method to facilitate computer supported education. Australasian Journal of Educational Technology, 24(4), 619-632. http: / / www.ascilite.org.au/ ajet/ ajet27 / garrote.html

Gervedink Nijhuis, C. J. (2012). Culturally sensitive curriculum development in international cooperation. Doctoral Thesis, University of Twente, Enschede.

Handelzalts, A. (2009). Collaborative curriculum development in teacher design teams. Doctoral Thesis University of Twente, Enschede. http: / / doc.utwente.nl/67385/1/thesis_A_Handelzalts.pdf

Hoven, K. (2000). A study on the potential of information and communication technologies in university education in Tanzania. A case study of the University of Dar es Salaam. MA thesis. The Netherlands: Nijmegen University.

Loucks-Horsley, S., Hewson, P. W., Love, N. \& Stiles, K. E. (1998). Designing professional development for teachers of science and mathematics. California: Corwin Press.

Mbwette, T. S. A. (2008). Welcome remarks by the chairman of the Tanzania Educational and Research Network (TERNET) council and vice chancellor of the Open University of Tanzania, Prof. T. S. A. Mbwette, on the official inauguration of TERNET held at Giraffe Ocean View Hotel, Dar es Salaam-Tanzania, 10 Sept, 2008.

Miles, M. B. \& Huberman, A. M. (1994). Qualitative data analysis: An expanded source book. 2nd Edition. London: SAGE Publications.

Mishra, P., Koehler, M. J. \& Zhao, Y. (2007). Faculty development by design: Integrating technology in higher education. Charlotte, NC: Information Age Publishing.

Mnyanyi, C. B. F. \& Mbwette, T. S. A. (2009). Open and distance learning in professional development in third world countries. Paper presented at Maastricht's 23rd International Conference on Distance Education, 2009. [viewed 25 Jun 2009] http: / / www.ou.nl/Docs/Campagnes / ICDE2009 / Papers / Final_paper_296Cosmas.pdf

Nihuka, K. A. \& Voogt, J. (2011a). Instructors' and students' competences, perceptions and access to e-learning technologies: Implications for e-learning implementation at the Open University of Tanzania. International Journal on E-Learning, 10(1), 63-85. http: / / www.editlib.org/p/32413

Nihuka, K. A \& Voogt, J. (2011b). Collaborative course design in TDTs: Experience in the Open University of Tanzania. International Journal of Learning Technologies, 6(2) 107-124. http: / / dx.doi.org/10.1504/IJLT.2011.042644

Nihuka, K. A. (2008). The feasibility of e-learning integration in course delivery at the Open University of Tanzania. Masters Thesis, University of Twente, Enschede.

Nihuka, K. A. (2011). Collaborative course design to support implementation of e-learning by instructors. Doctoral thesis, University of Twente, Enschede. http: / / doc.utwente.nl/78096/1/thesis_K_Nihuka.pdf

Parke, H. M. \& Coble, C. R. (1997). Teachers designing curriculum as professional development: A model for transformational science teaching. Journal of Research in Science Teaching, 34(8), 773-789. http: / / dx.doi.org/10.1002 / (SICI)1098-2736(199710)34:8<773::AID-TEA2>3.0.CO;2-S

Penuel, W. R., Fishman, B. J., Yamaguchi, R. \& Gallagher, L. P. (2007). What makes professional development effective? Strategies that foster curriculum implementation. American Educational Research Journal, 44(4), 921-958. http: / / dx.doi.org/10.3102/0002831207308221

Poumay, M., Dupont, C., Georges, F. \& Leclercq, D. (2001). Support, training and regulation as key success factors in developing e-learning - Cases study of the LabSET-ULg, in Belgium. Paper presented at the 2nd WBLE Conferences, Lund, Sweden. 
Smolin, L., Lawless, K., Radinsky, J. \& Newman, M. (2003). School-university collaborative design teams: Curriculum design as a vehicle for professional development in teaching with technology. In C. Crawford et al. (Eds.), Proceedings of Society for Information Technology $\mathcal{E}$ Teacher Education International Conference 2003 (pp. 3775-3778). Chesapeake, VA: AACE. http: / / www.editlib.org/p/18822

Resta, P. \& Laferriere, T. (2008). Issues and challenges related to digital equity. In J. Voogt \& G. Knezek (Eds.), International handbook of information technology in primary and secondary education (pp. 765-778). New York: Springer.

Sife, A. S., Lwoga, E. T. \& Sanga, C. (2007). New technologies for teaching and learning: Challenges for higher learning institutions in developing countries. International Journal of Education and Development using Information and Communication Technology, 3(2), 57-67. http: / /ijedict.dec.uwi.edu / include / getdoc.php?id=2385\&article=246

Telnova, T. (2005). Development of template for learning objectives within the learning content management system eXact for Digitale Universiteit. Masters Thesis, University of Twente, Enschede.

Thousand, J. S. \& Villa, R. A. (1993). Collaborative teams: A powerful tool to school restructuring. In R. A. Villa, J. S. Thousand, W. Steinback \& S. Steinback (Eds.), Restructuring for caring and effective education: An administrative guide to creating heterogeneous schools (pp. 73108). Baltimore: Brookes Publishing.

Uys, P. M. (2010). Implementing an open source learning management system: A critical analysis of change strategies. Australasian Journal of Educational Technology, 26(7), 980-995. http: / / www.ascilite.org.au/ajet/ajet26/uys.html

Voogt, J. (2010). A blended in-service arrangement for supporting science teachers in technology integration. Journal of Technology and Teacher Education, 18(1), 83-109. http: / / editlib.org/p/28359

Voogt, J., Almekinders, M., van den Akker, J. \& Moonen, B. (2005). A 'blended' in-service arrangement for classroom technology integration: Impacts on teachers and students. Computers in Human Behavior, 21(3), 523-539. http: / / dx.doi.org/10.1016/j.chb.2004.10.003

Waddoups, G. L., Wentworth. N. \& Earle, R. (2004). Principles of technology integration and curriculum development: A faculty design team approach. Computers in the Schools, 21(1-2), 15-23. [viewed 15 Oct 2010, verified 29 Feb 2012]. http: / / essentialconditionswiki.pbworks.com/f/CurrDesignTeam.pdf

Yin, R. K. (2003). Case study research design and methods (3rd Edition). Applied social research methods series, Volume 5. SAGE Publications.

Authors: Kassimu A. Nihuka (corresponding author)

Lecturer, Institute of Continuing Education

Open University of Tanzania, PO Box 23409, Dar es Salaam, Tanzania

Email: kassim.nihuka@out.ac.tz

Dr Joke Voogt, Faculty of Behavioural Sciences

University of Twente, Box 217, 7500 AE, Enschede, Netherlands

Email: j.m.voogt@gw.utwente.nl

Please cite as: Nihuka, K. A. \& Voogt, J. (2012). Collaborative e-learning course design: Impacts on instructors in the Open University of Tanzania. Australasian Journal of Educational Technology, 28(2), 232-248.

http:/ / www.ascilite.org.au/ajet/ajet28/nihuka.html 